\title{
PENALARAN HAKIM MENERAPKAN AJARAN PENYERTAAN DALAM PUTUSAN TINDAK PIDANA KORUPSI PADA BANK RIAU-KEPRI*.
}

\author{
Muhammad Musa \\ Fakultas Hukum Universitas Islam Riau Pekanbaru \\ Jalan Kaharuddin Nasution No. 113 Pekanbaru 24284 \\ musa@law.uir.ac.id
}

\begin{abstract}
The differences of judge reasoning on the corruption cases convictions that occurs at Riau-Kepri Bank lending, appears as a problem in determining the guilty actions of the defendants participated in the case. The Basic problems studied is of the judges reasoning in determining the guilt and criminal elements, as well as the construction of reasoning of the judges in applying the teachings of inclusion. From the research findings, the action of the three defendant of Riau-Kepri Bank as credit providers were found guilty and convicted. Credit receiver was concluded free from all charges. The construction of judges reasoning, the participating actions committed by the loan recipient, can not be criminally liable due to the fulfillment of elements of tort within the scope of civil law.
\end{abstract}

Keywords: The Judge reasoning, participation, guilt, crime, corruption.

\begin{abstract}
Abstrak
Perbedaan penalaran hakim memutus perkara korupsi pemberian kredit yang terjadi di Bank RiauKepri,menjadi persoalan yuridis ketika menentukan kesalahan perbuatan turut serta para terdakwa. Permasalahan yang diteliti adalah tentang konstruksi pemikiran hakim menentukan unsur tindak pidana dan kesalahan para terdakwa. Urgensi penelitian ini untuk memahami pilihan prakis hakim menggunakan ajaran penyertaan, ketika menerapkan Pasal 55 KUHP dalam mengadili perbuatan turut serta. Pendekatan penelitian yang digunakani yuridis empiris dengan spesifikasi penelitian hukum normatif. Temuan penelitian, bahwa perbuatan pemberi kredit dari Bank Riau-Kepri terbukti bersalah dan dipidana. Penerima kredit diputus lepas dari segala tuntutan hukum. Konstruksi penalaran hakim, perbuatan penerima kredit tidak dapat dipertanggungjawabkan secara pidana karena perbuatan yang terbukti masuk dalam lingkup hukum perdata.
\end{abstract}

Kata kunci: Penalaran hakim, turut serta, tindak pidana korupsi.

\section{A. Pendahuluan}

1. Latar Belakang Permasalahan

Penalaran hukum yang dilakukan hakim merupakan kegiatan berpikir problematis hakim dalam memeriksa dan mengadili perkara, baik perkara perdata, perkara pidana dan perkara lainnya. Dari perkara pidana yang diadili selalu ditemukan pelakunya terdiri dari beberapa orang pelaku, yang didalam ilmu hukum pidana disebut penyertaan tindak pidana. Pada kasus-kasus tindak pidana korupsi, melibatkan beberapa orang pelaku ini sering disebut "korupsi berjamaah". Untuk mengadili kasus-kasus seperti ini, kecermatan hakim ketika menilai tindak pidana dan kesalahan terakwa menjadi kunci dalam menentukan pidana yang dijatuhkan. Penalaran hakim akan menjadikan konsekuensi yuridis dari "ketokan palu" yang dijatuhkan. Walaupun pada ketentuan Pasal 55 ayat (1) KUHP telah menentukan bahwa dipidana sebagai pelaku

\footnotetext{
* Hasil penelitian ini didanai oleh Lembaga Penelitian Universitas Islam Riau pada tahun 2016. Penelitian dilakukan dalam rangka program kegiatan penelitian dosen pada Lembaga Penelitian UIR dengan Kontrak No. 235/Kontrak/LPUIR/7-2016 dan telah dilakukan seminar hasil penelitian pada tanggal 14 Januari 2017.
} 
tindak pidana: mereka yang melakukan, yang menyuruh melakukan, dan yang turut serta melakukan perbuatan.

Pada tataran ius operatum ketentuan norma Pasal 55 ayat (1) KUHP yang selalu digunakan untuk menjerat keterlibatan para pelaku tindak pidana korupsi, tidak semudah yang digambarkan dan selalu terjadi perbedaan pada pemahaman hakim. Perbedaan itu timbul karena penalaran yang berbeda, baik perbedaan pandangan dalam tim majelis yang disebut dengan istilah dissenting opinion maupun perbedaan antara putusan judex facti dan judex jure. Salah satu contoh perkara yang populer seperti kasus videotron, perkara tindak pidana korupsi proyek pengadaan videotron pada Kantor Kementerian Koperasi dan Usaha Kecil Menengah (UKM) Republik Indonesia. salah satu terdakwanya seorang Office Boy yang direayasa menjadi direktur suatu Perseroan Terbatas dengan tujuan untuk memenangkan proyek pengadaan videotron di Kantor Kementerian Koperasi dan UKM. Majelis hakim pada peradilan tingkat pertama yang memutus perkara terjadi dissenting opinion ketika menentukan tindak pidana dan kesalahan masing-masing terdakwa yang diadili. Perbedaan penalaran tentang tindak pidana dan kesalahan itu semakin tajam antara putusan pemidaaan yang dibuat judex facti, tetapi perkara tersebut sebaliknya diputus lepas dari segala tuntutan hukum pada tingkat judex jure.

Diskrepansi prinsipil penalaran hakim dalam menentukan tindak pidana dan pertanggungjawaban pidana dari perbuatan turut serta dalam tindak pidana korupsi yang diteliti, belum ada ditemukan penelitian terdahulu yang terpublikasi. Tindak pidana korupsi yang diteliti ini melibatkan tiga jajaran pimpinan Bank Riau-Kepri dalam memberikan kredit dan take over proyek pembangunan mall terhadap satu orang pihak swasta, dan terbukti dipersidangan kredit tersebut masuk kategori kredit macet. Dalam putusan yang berbeda, ketiga terdakwa dari jajaran Bank Riau-Kepri masing-masing dikenakan pidana karena terbukti perbuatan dan kesalahannya. Terdakwa dari pihak swasta diputus lepas dari segala tuntutan hukum, karena perbuatannya tidak terbukti sebagai tindak pidana dan tidak ada unsur kesalahan.

\section{Kerangka Teori}

Teori yang digunakan sebagai pisau analisis pada penelitian ini digunakan beberapa teori. Teori metoda penalaran dijadikan dasar untuk memahami penalaran hakim dalam membuat pertimbangan dan keputusan perkara. Secara teoretis dikenal beberapa bentuk penalaran, selaian "penalaran deduksi dan penalaran induksi yang diawali dengan pengamatan" (Blackburn, 2013), ada pula "penalaran gabungan yang disebut penalaran abduksi" (Dimyati, 2014). Ketiga jenis penalaran itu merupakan kegiatan proses berpikir untuk menemukan kebenaran dalam membuat suatu pertimbangan keputusan. Dari sisi substansi hukum yang diputus hakim yang terkait dengan tindak pidana dan pertanggngjawaban pidana, dalam penelitian ini digunakan sebagai pisau analisis berkaitan dengan teoriteori aliran hukum pidana yang merumuskan perbuatan dan pertanggungjawaban pidana. Ada dua aliran atau pandangan dalam hukum pidana, yaitu aliran monistis dan aliran dualistis. Karena subyek penelitian menyangkut tentang perbuatan penyertaan (deelneming), maka teori perluasan penyertaan dalam ilmu hukum pidana menjadi dasar penentu untuk menganalisis tentang pertanggungjawaban pidana bagi masing-masing pelaku. Dalam konsep aliran monistis dan dualistis ketika menentukan perbuatan pidana (tindak pidana) terdapat perbedaan mendasar, hal ini menyebabkan perbedaan pandangan pula pada penerapan sistem pemidanaan yang terkait dengan pembuat pada turut serta dalam tindak pidana. Aliran monistis dalam ajarannya memandang penyertaan merupakan dasar untuk memperluas dapat dipidananya orang (strafausdehnungsgrund), dan dilain pihak bagi aliran dualistis melihat "penyertaan sebagai untuk memperluas dapat dipidananya perbuatan (tatbestand ausdehnungsgrund)" (Arief, 2015). Kedua pandangan dalam ajaran penyertaan ini menjadi dasar teori untuk menganalisis tindak pidana pembuat turut serta pada obyek penelitian. 
3. State of The Art Penelitian Sebelumnya

Dalam penelusuran penulis, ada tiga penulis yang ditemukan melakukan penelitian terdahulu. Penelitian terhadap "Penerapan ajaran penyertaan dalam peradilan pidana Indonesia" yang dilakukan Surastini Fitriasih (Fitriasih, 2006), dan penelitian masalah "Pola Penalaran Hukum Dalam Kajian Putusan Kasus Tanah Adat" yang dilakukan Shidarta (Shidarta, 2010). Terakhir ditemukan pada suatu laporan penelitian tentang "Tanggung Jawab Pelaku Penyertaan Dalam Tindak Pidana" yang dilakukan Aknes Susanty Sambulele (Sambulele, 2013). Ketiga penelitian ini mempunyai sisi perbedaan mendasar dari yang penulis teliti, optik penelitian penulis terkait dengan memahami penalaran hakim menggunakan ajaran penyertaan dalam memutus penyertaan tindak pidana korupsi.

\section{Permasalahan}

Dari keadaan latar belakang putusan hakim terhadap perbuatan turut serta dalam perkara tindak pidana korupsi tersebut, terlihat adanya diskrepansi penalaran hakim dari keempat putusan perkara tindak pidana korupsi yang diadili. Esensi persoalan yang dilakukan telaah secara akademis dalam penelitian ini, dengan rumusan masalah:

a. Bagaimanakah penalaran hakim dalam menentukan unsur tindak pidana dan kesalahan pada pembuat turut serta tindak pidana korupsi pemberian kredit Investasi Bina Prima pada BPD. Riau Kepri?

b. Bagaimanakah konstruksi penalaran hakim dalam menerapkan ajaran penyertaan pada delik penyertaan tindak pidana korupsi pemberian kredit Investasi Bina Prima di BPD. Bank Riau Kepri?

\section{Metode Penelitian}

Metode pendekatan penelitian menurut Rony Hanitijo Soemitro ada dua, yaitu yuridis normatif dan yuridis empiris (Soemitro, 1990). Pada penelitian ini menggunakan pendekatan yuridis empiris, dengan spesifikasi penelitian hukum normatif. Jenis data yang dikumpulkan berupa data primer diri empat orang hakim ad hoc sebagai responden, dengan teknik pengumpulan data berupa wawancara. Data sekunder diambil dari empat dokumen putusan pengadilan dari tindak pidana korupsi pemberian kredit investasi bina prima pada Bank Riau-Kepri. Analisis data menggunakan metoda analisis normatif-kualitatif yang disajikan dalam bentuk deskriptif.

\section{B. Hasil dan Pembahasan}

1. Penalaran Hakim Menentukan Tindak Pidana dan Kesalahan Pelaku Turut Serta Tindak Pidana Korupsi

a. Penalaran Hakim dalam Menentukan Unsur Tindak Pidana

Dari temuan hasil penelitian terhadap ke empat (4) perkara, yang terbukti dalam dakwaan primer, melanggar ketentuan Pasal 2 Ayat (1) Jo. Pasal 18 Undang-Undang Nomor 31 Tahun 1999 jo Pasal 55 Ayat 1 ke(1) KUHP. Dakwaan primer pada surat dakwaan Penuntut Umum meliputi unsurunsur: Setiap orang, secara melawan hukum, memperkaya diri sendiri atau orang lain atau suatu korporasi, dapat merugikan keuangan negara atau perekonomian negara. Unsurunsur Pasal 55 ayat (1) Ke-1 KUHP: "Yang melakukan, menyuruh melakukan, atau turut serta melakukan perbuatan itu." Penalaran hakim terhadap setiap unsur tindak pidana dalam pertimbangan hukum ke empat nomor putusan yang diteliti, merupakan esensi terpenting dari pekerjaan seorang hakim. Kendati demikian, menurut Shidarta bahwa penalaran itu tidak boleh dilakukan sekehendak hati tetapi harus reasonable dan bukan semata logical (Shidarta, 2006).

Pertimbangan hukum yang dibuat hakim terhadap unsur-unsur Pasal 2 ayat (1) Undang-undang Tindak Pidana Korupsi tersebut, terdapat perbedaan keriteria dalam menentukan unsur perbuatan pidana dan kesalahan para terdakwa. Logika penalaran masing-masing majelis hakim terlihat mendasarkan syllogisme berpikir metoda deduktif ketika menentukan unsur tindak pidana. Pembuktian unsur "setiap orang" terhadap masing-masing terdakwa, hakim melakukan penalaran yang bertolak dari fakta dalam menentukan subyek, dengan menarik 
diri terdakwa ke dalam unsur norma. Dari syllogisme yang dilakukan majelis hakim melahirkan beberapa istilah untuk menentukan terbuktinya diri terdakwa sebagai subyek pelaku tindak pidana.

Langkah-langkah penalaran hakim dalam deskripsi perkara ini bertolak dari langkah-langkah analisis berbasis kepada format positifisme hukum. Menurut Bernard Arief Sidharta: "Model kepastian hukum, argumentasi yang dilakukan mengikuti asas asas similia similibus sebagai penalaran yang relative terjaga konsistensinya" (Sidharta.B, 2000). Dari penalaran hakim dalam memaknai pengertian unsur "setiap orang" terhadap para terdakwa dinilai telah terbukti. Pertama; Terdakwa terbukti sehat jasmani dan rohani serta mengetahui dan menghendaki (wettens en wellens) perbuatannya beserta akibatnya. Kedua, terdakwa mempunyai kemampuan untuk membedan perbuatan baik dan buruk. Ketiga, terdakwa mempunyai kemampuan bertanggungjawab secara pidana. Ada pula majelis hakim yang berpendapat, bahwa pengertain "setiap orang" tidak termasuk dalam unsur tindak pidana, namun demikian penting dipertimbangkan dalam pembuktian untuk menghindari kesalahan orang (error in persona) dalam peradilan pidana.

Pengertian unsur "melawan hukum" pada delik penyertaan tindak pidana korupsi, ada beberapa hal dalam pembuktian yang dipertimbangan hakim dari keempat putusan. Majelis Hakim menilai perbuatan para terdakwa dari pejabat Bank Riau-Kepri terbukti melawan hukum. Dasar penilaian: Pertama, adanya kesepakatan antara ketiga pejabat bank untuk merencanakan proses take over atas permohonan kredit dari pemohon kredit yang sebenarnya tidak layak dan tidak memiliki persyaratan yang lengkap. Kedua, karena pejabat bank terbukti telah membuat disposisi untuk pembuatan analisa pembahasan permohonan permohonan kredit yang diketahui tidak memenuhi syarat. Perbuatan memberi disposisi tersebut, merupakan perbuatan mengabaikan ketentuan perundang-undangan perbankan sebagai perbuatan melawan hukum. Ketiga, karena dipercaya sebagai pimpinan cabang akan tetapi tidak melakukan perbuatan yang seharusnya yaitu menyeleksi dokumen permohon kredit, verifikasi data, dan pembuatan asumsi. Perbuatan dari pihak swasta sebagai penerima kredit, dinyatakan melawan hukum karena terjadinya keputusan Pejabat Bank Rau-Kepri mengabulkan permohonan, atas dasar permohonan dan kesediaan Terdakwa untuk melakukan take over kredit. Dengan memperhatikan prinsip kausalitas, maka perbuatan terdakwa adalah melakukan perbuatan yang melanggar peraturan perundang-undang.

Untuk pembuktian perbuatan para terdakwa tentang unsur "memperkaya diri sendiri atau orang lain atau suatu korporasi", ditemukan penalaran hakim dalam pertimbangan terhadap pebuatan ZT, BA, dan YS. Para terdakwa dinyatakan terbukti memperkaya diri orang lain atau korporasi. Bentuk perbuatan para terdakwa berupa rangkaian perbuatan saling terkait hingga tindakan pencarian kredit terjadi. Penerbitan SP3K oleh ZT dan BA yang menyetujui perubahan syarat dalam pemberian kredit dalam disposisi, sehingga dilakukan pencairan kredit oleh YS merupakan bentuk perbuatan yang memperkaya penerima kredit (AW) sebagai Direktur PT. SPB. Terdakwa menggunakan uang kredit investasi tidak sesuai dengan ketentuan yang berlaku dalam kontrak dan perundang-undangan, merupakan bentuk perbuatan yang memenuhi unsur menguntungkan diri sendiri atau korporasi.

Penalaran hakim terhadap unsur "merugikan keuangan negara atau perekonomian negara", ditemukan dalam pertimbangan hukum yang lebih menekankan pada sisi akibat dari peran perbuatan masingmasing terdakwa. Hakim dalam memahami unsur "merugikan keuangan negara atau perekonomian negara" sebagai unsur yang bersifat alternatif, antara yang dapat merugikan keuangan negara atau perekonomian negara. Pada perkara delik penyertaan tindak pidana korupsi ini, ternyata hakim cukup membuktikan salah satu dari yang dapat dirugikan akibat perbuatan pelaku tindak pidana. Konstruksi penalaran hakim untuk menentukan hubungan kata "dapat" dengan "merugikan keuangan negara" 
menggambarkan dua hubungan yang ekstrim

: (1) nyata-nyata merugikan negara (actual loss) atau (2) kemungkinan dapat menimbulkan kerugian (potential loss). Berdasarkan ketentuan Pasal 1 ayat 22 Undang-Undang No.1 Tahun 2004 tentang Perbendaharaan Negara, maka dalam perkara ini terdapatnya sejumlah uang sebesar Rp.35.200.000.000,- (tiga puluh lima milyar dua ratus juta rupiah) tersebut tidak dapat dipertanggung jawabkan ZT dan jajarannya untuk mengelola dana Bank Riau-Kepri. Keterlibatan ZT, dan BA serta YS dalam pemberian kredit terhadap AW, mengakibatkan keuangan Provinsi Riau mengalami kerugian nyata (total loss) sebesar Rp.35.200.000.000,- (tiga puluh lima milyar dua ratus juta rupiah).

b. Penalaran Hakim dalam Menentukan Unsur Kesalahan dalam Perbuatan Turut Serta

Dilihat dari sistem pemidanaan, perbuatan pidana (starbaarfeit/criminal act/actus reus) atau tindak pidana merupakan salah satu dari tiga masalah pokok dalam hukum pidana (Arief, 2012). Untuk menentukan dapat tidaknya dikenakan pidana kepada seseorang ditentukan dari unsur perbuatan obyektif dan subyektif pelaku. Perbuatan lahiriah merupakan elemen luar (external element) yang dikenal dengan intilah actus reus, sebagai penentu adanya unsur obyektif suatu perbuatan pidana. Keadaan batin dari pelaku sebagai keadaan subyektif yang terdapat pada jiwa pelaku, dikenal dengan istilah mens rea adalah unsur kesalahan (fault element) atau unsur mental (mental element).

Dari kedua elemen ini akan menentukan dapat tidaknya seseorang untuk dipidana. Dari pembuktian di persidangan pada perkara tindak pidanan korupsi ini, majelis hakim telah meyakini keadaan subyektif ke tiga (3) terdakwa Pejabat Bank Riau-Kepri telah memenuhi unsur-unsur kesalahan. Berbeda dengan ketiga terdakwa, perbuatan turut serta AW sebagai penerima kredit, majelis hakim meyakini perbuatan terdakwa tidak ada terdapat unsur kesalahan yang dapat dipertanggungjawabkan secara pidana. Hakim berpandangan bahwa tidaklah setiap perbuatan turut serta itu dipandang menjadi kesatuan sebagai tindak pidana.

Dalam penalaran hakim yang ditemukan pada perkara, ada keterpisahan perbuatan terdakwa AW yang bernuansa lain. Walaupun unsur perbuatan turut serta terdakwa merupakan suatu kenyataan sebagai delik penyertaan, tetapi tidak memenuhi sifat kesalahan dari perbuatan turut serta tindak pidana. Penjelasan Hakim yang mengadili salah satu perkara menggambarkan tentang perbuatan penyertaan dalam tindak pidana korupsi, masing-masing hakim dalam majelis mempunyai pemahaman yang berbeda terhadap fakta yang ditemukan dipersidangan. Hakim yang mengadili terdakwa AW ternyata membentuk penalaran yang bertolak dari metoda induksi. Kerangka berpikir hakim berupaya melakukan pemisahan antara unsur tindak pidana dengan kesalahan. Fakta ini memperlihatkan bahwa hakim telah menggunakan ajaran penyertaan yang memandang penyertaan sebagai memperluas dapat dipidananya perbuatan. Penalaran demikian, dalam rangka untuk menentukan dapat dipidananya perbuatan masing-masing pelaku dilihat dari kesalahan individu, dan bukan atas dasar perbuatan fisik yang dilakukan secara bersama-sama sebagai strafbaarfeit. Pemikiran hakim ini didasari pada pemikiran yang memisahkan perbuatan dengan kesalahan yang dikenal pada aliran dualistis. Ketentuan delik penyertaan dalam ketentuan Pasal 55 KUHP yang berbasis aliran monistis menjadi persoalan di dalam praktek. Gambaran putusan terhadap Perbuatan dan Kesahan pada perkara ini sbb:

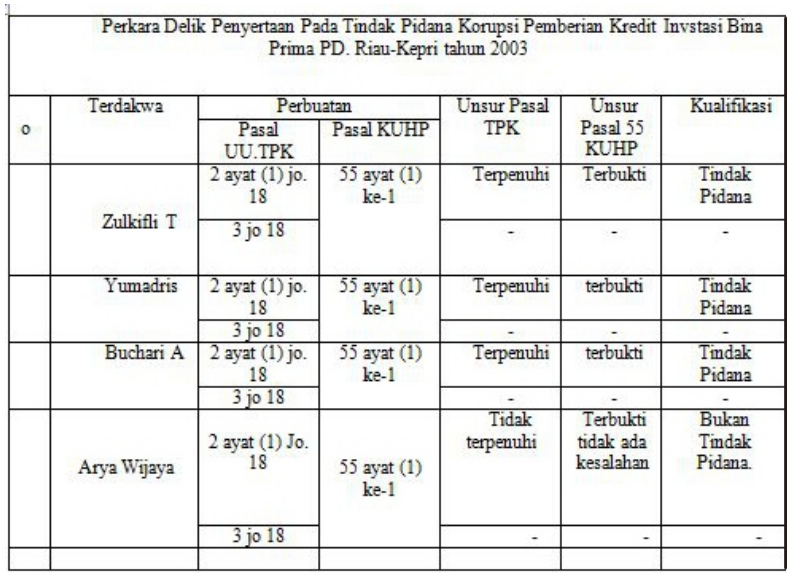

Menurut Roeslan Saleh, mereka yang turut 
serta melakukan adalah mereka yang bersama-sama dengan sengaja melakukan tindak pidana. Dalam pelaksanaan tindak pidana itu yang paling utama haruslah adanya kerja sama yang erat di antara mereka itu, sehingga tiap-tiap peserta tidak harus melakukan perbuatan-perbuatan pelaksanaan (Saleh, 1987). Kerja sama secara sadar dalam turut serta melakukan itu harus berkaitan dengan dipenuhinya bagian tindak pidana, jika kerja sama itu tidak ada maka tidak dapat dikatakan turut serta rnelakukan, sehingga logis jika dikatakan bahwa turut serta melakukan hanya mungkin terjadi kalau ada kesengajaan (Saleh, 1997). Penjelasan hakim yang memutus perkara, bahwa pada perbuatan turut serta tersebut ada semacam pembagian kerja dengan tanggung jawab yang dibebankan kepada kelompok secara bersama-sama, tetapi kadang kala adanya suatu kerjasama terbukti namun sebagai medepleger tidak diisyaratkan untuk bertanggungjawab karena tidak ada kesalahan. Pemikiran tersebut merupakan hal yang sama dengan yang mendasari pemikiran majelis ketika melihat perbuatan terdakwa AW pemohon dan penerima kredit. Di dalam subyektifitas terdakwa AW tidak ada terdapat kesalahan sebagaimana yang terdapat pada diri terdakwa ZT, BA dan YS. Macetnya pembayaran kredit yang disepakati dalam perjanjian merupakan ruang lingkup hubungan keperdataan.

\section{Konstruksi Penalaran Hakim dalam Menerapkan Ajaran Penyertaan pada Tindak Pidana Korupsi}

Pada dasarnya perbuatan turut serta melakukan tindak pidana, ada terdapat keriteria, yaitu kerja sama yang disadari dan pelaksanaan bersama-sama (Farid \& Hamzah, 2002). KUHP yang menganut prinsip-prinsip monistis, konsekuensinya rumusan ajaran turut serta berfungsi untuk memperluas pertanggungjawaban pidana (Utrecht, 1965), sebagai implementasi pemikiran ajaran penyertaan tentang perluasan dapat dipidananya orang. Dari putusan hakim tingkat pertama pada tindak pidana korupsi ini, mencerminkan adanya suatu pergeseran paradigma hakim dalam meletakkan kerangka perbuatan turut serta dari fakta terhadap norma Pasal 55 ayat (1) ke-1 KUHP. Teori perluasan ajaran penyertaan yang diterapkan hakim baik pada putusan judex factie dan judex jure dapat digambarkan pada bagan berikut:
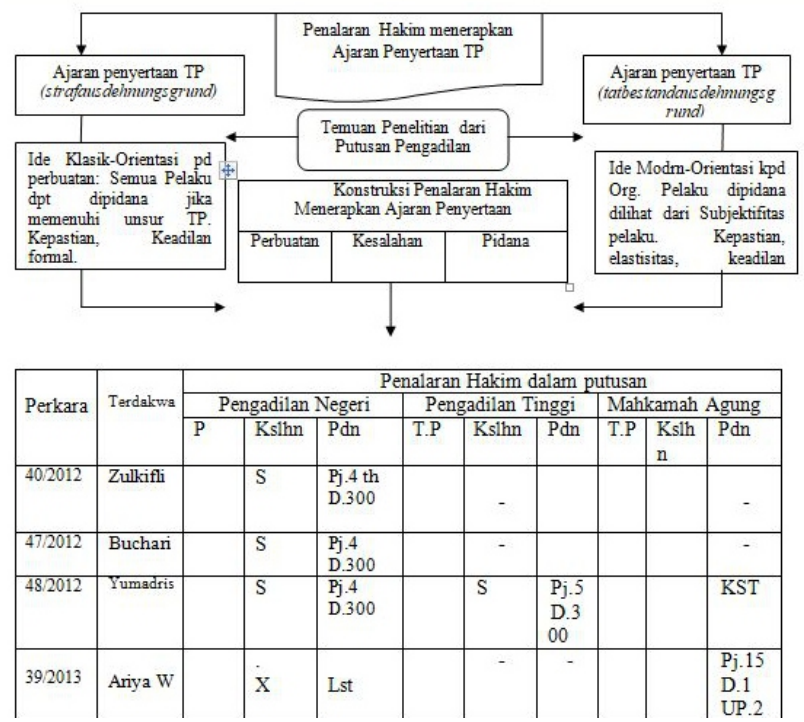

Penjelasan:

$\mathrm{P}=$ Pelaku; $\mathrm{T}=$ Turut serta; $\mathrm{S}=$ Sengaja; $\mathrm{X}=$ Sengaja tapi bukan perbuatan pidana; $\mathrm{Pj} .4 \mathrm{th}=$ Penjara 4 tahun; Pj. 5 = Penjara 5 tahun; Pj.15 = Penjara 15 tahun; D.300 = Denda 300 juta; D.1 = Denda satu milyar; UP.2 = Uang Pengganti dua milyar; KST = Kasasi ditolak; Lst $=$ Lepas dari segala tuntutan hukum.

Penalaran hakim dalam perkara ini pada satu sisi bertolak dari langkah-langkah analisis berbasis kepada format positifisme hukum, dengan cara penalaran doktrinaldeduktif. Ketentuan norma dikukuhkan sebagai premis mayor yang menjadi sarana pencapaian kepastian hukum. Inti kepastian hukum menurut Shidarta adalah prediktibilitas, yakni kemampuan mempersepsikan "an individual ought to behave in a certain way" (Shidarta, 2013). Menurut Abdullah, bahwa model penalaran hakim menganalisis kasus menggunakan hukum tertulis sebagai hukum primeir, norma hukum positif diasumsikan sudah dibuat dengan memperhatikan prinsip-prinsip filosofis, kandungan nilai-nilai serta asas-asas kebenaran dan keadilan (Abdullah, 2008). Konsekuensi dari cara penalaran ini menurut 
pandangan Shidarta, penegak hukum ditunutut untuk dapat memberikan makna secara tepat (Shidarta, 2013). Untuk mencari kebenaran obyektif dari putusan perkara, ketepatan penalaran hakim menentukan perbuatan dan pertanggungjawaban pidana sebagai penentu masalah pemidanaan dari masing-masing pembuat dalam delik penyertaan. Ketika hakim mengadili delik penyertaan tersebut dalam pandangan Fitriasih, penalaran hakim berperan penting dalam mengembangkan ajaran delik penyertaan dan turut serta (Fitriasih, 2006).

Secara prinsipil penalaran hakim ditujukan untuk memperluas prinsip adjudikasi (principle of adjudication) yang digunakan oleh hakim sebagai pedoman dalam menentukan keadaan-keadaan tertentu untuk dapat dipertanggungjawabkan kepada pembuat tindak pidana. Terkait dengan mengadili delik penyertaan, ada dikenal teori penyertaan subyektif dan teori penyertaan obyektif. Menurut Moeljatno, bahwa teori campuran ini merupakan teori penjelasan ajaran penyertaan sebagai perluasan pertanggungjawaban pidana (Moeljatno, 1985). Di satu sisi, teori penyertaan subjektif menyebutkan bahwa'pemidanaan terhadap pembuat (pelaku pesuruh, pelaku turut serta danpenganjur) memiliki derajat yang sama didasarkan pada niat subjektif para pembuat.

Di sisi lain, teori penyertaan objektif mendasarkan pemidanaan yang berbeda-beda berdasarkan perbuatan objektif yang terwujud dalam penyertaan. Penalaran hakim terhadap penentuan perbuatan turut serta pada perkara ini menunjukkan adanya pengaruh pemikiran pemisahan perbuatan dan pertanggngjawaban pidana yang berimplikasi terhadap pemidanaan. Walaupun perbuatan turut serta terdakwa diyakini terbukti namun sifat perbuatan terdakwa AW tidak digolongkan sebagai tindak pidana, dan perbuatan para terdakwa dari pihak bank dipandang memenuhi unsur dari sifat perbuatan turut serta melakukan tindak pidana. Pertimbangan hakim tentang fakta yang diperoleh dari pememeriksa alat bukti, menjadi patokan hakim ketika melakukan penalaran dan menentukan keyakinan terbukti tidaknya tindak pidana. Perbedaan penalaran hakim melihat objek tindak pidana korupsi tersebut, ternyata memiliki dampak pula dalam menilai kesalahan dan menentukan pemidanaan. Alur metoda penalaran hakim memaknai perbtuatan turut serta para terdakwa dapat digambarkan sebagai mana yang ditulis secara etalic pada bagan berikut:

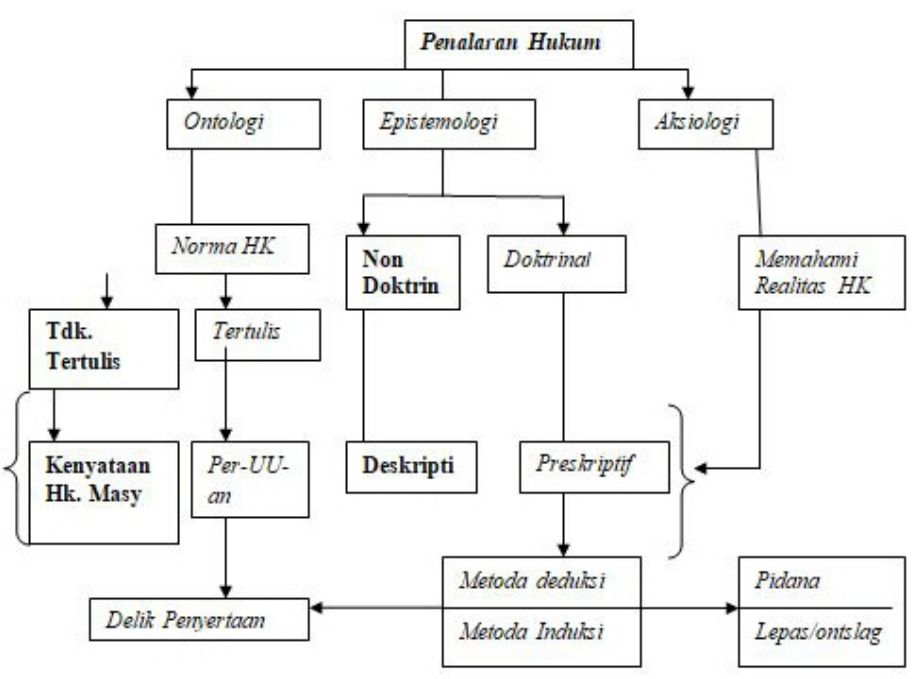

tahun 2016.

Pemikiran majelis hakim ketika mempertimbangkan hubungan hukum dari kontrak yang dibuat antara Pejabat BPD. Riau-Kepri dengan Direktur PT. SPB, dinyatakan tidak terbukti ada kesalahan pada AW. Dasar pemikiran hakim judex factie mengacu kepada ketentuan Pasal 8 UndangUndang Nomor: 7 Tahun 1992 tentang Perbankan. Pejabat Bank Umum sebelum memberikan kredit, wajib terlebih dahulu memiliki keyakinan atas kemampuan dan kesanggupan debitur melunasi hutang sesuai dengan yang diperjanjikan. Dalam praktik pelaksanaan prinsip keyakinan tersebut, Bank Umum sebelum memberikan kredit terlebih dahulu menentukan syarat-syarat yang harus dipenuhi oleh debitur. Pejabat Bank wajib meneliti caracter, capacity, dan capital calon debitur untuk memastikan kemampuannya. Dengan terjadinya pelanggaran kontrak, menurut hakim kesalahan yang timbul pada debitur berbeda dengan pejabat publik. Perbuatan terdkwa AW dinilai terbukti, namun masuk pada wilayah hukum privat. 
Gambaran perbuatan melawan hukum dari tindak pidana turut serta dari Pejabat Bank dan Pihak Swasta pada putusan hakim dapat digambarkan sebagai berikut:

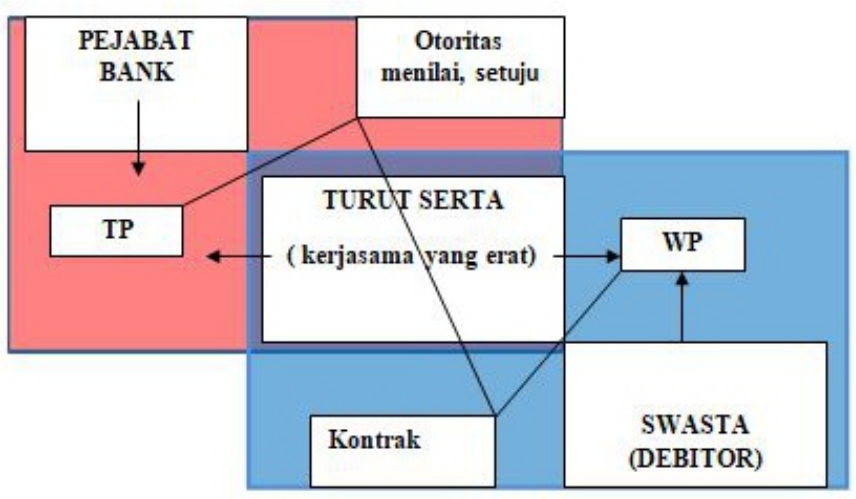

Note: $\mathrm{TP}=$ Tindak Pidana, $\mathrm{WP}=$ Wanprestasi.

Dalam bagan tersebut menggambarkan pembebanan perbuatan sebagai tindak pidana berada pada pihak pejabat bank, yang telah mempunyai kesepakatan memberikan penilaian kelayakan terhadap pihak debitor. Perbuatan turut serta dari terdakwa AW sebagai debitor dipandang tidak terdapat unsur niat jahat, melainkan hanya terbukti melanggar point kesepakatan kontrak.

\section{Simpulan}

1. Penalaran hakim menentukan unsur tindak pidana korupsi terhadap perbuatan para terdakwa berangkat dari pemikiran deduktif. Restriksi penalaran hakim terhadap perbuatan melawan hukum (wederechtelijk) sama dengan melanggar undang-undang (wet). Terkait dengan masalah sifat perbuatan, majelis hakim judex factie melihat relasi perbuatan terdakwa penerima pekerjaan yang tidak melaksanakan pekerjaan dengan tuntas adalah masuk kategori melawan hukum dalam ranah hukum perdata.

2. Konstruksi penalaran hakim dari dalam menentukan perbuatan dan kesalahan para terdakwa sebagai dasar pemidanaan terhadap ketentuan turut serta dari Pasal 55 ayat (1) ke-1 KUHP, masih mempertahankan doktrin klasik dengan konsep perbuatan secara fisik.
Penentuan perbuatan dan kesalahan para terdakwa, norma sebagai premis mayor menjadi faktor penentu. Relasi unsurunsur obyektif ketentuan pasal tentang perbuatan turut dari ketentuan Pasal 55 ayat (1) ke-1 KUHP sudah dipandang menggambarkan kenyataan subyektifitas dari pelaku tindak pidana

\section{DAFTAR PUSTAKA}

Abdullah. (20008). Pertimbangan Hukum Putusan Pengadilan. Surabaya: Bina Ilmu.

Arief, Barda, N. (2012). RUU KUHP Baru Sebuah Restrukturisasi/Rekonstruksi Sistem Hukum Pidana Indonesia. Semarang: Badan Penerbit Universitas Diponegoro.

----------.. (2015). Sari Kuliah Hukum Pidana Lanjut. Semarang: Penerbit Universitas Diponegoro.

Blackburn, S. (2013). Kamus Filsafat Buku Acuan Paling Terpercaya di Dunia, Ed.Rev ke-2 Terjemahan Yudi Santoso. Yogyakarta: Penerbit Pustaka Pelajar.

Dimyati, Kh. (2014). Pemikiran Hukum Konstruksi Epistemologis Berbasis Budaya Hukum Indonesia. Yogyakarta: Genta Publishing.

Farid Andi, Z., \& Hamzah, A. (2002). Bentukbentuk Khusus Penwujudan Delik dan Hukum Penetensier. Jakarta: Sumber Ilmu Jaya.

Moeljatno. (1985). Hukum Pidana: Delikdelik Percobaan Delik-delik Penyertaan. Jakarta: Bina Aksara.

Soemitro, Rony.H,. (1990). Metodologi Penelitian Hukum dan Jurimetri. Jakarta: Ghalia Indonesia.

Saleh, R. (1987). Kitab Undang-Undang Hukum Pidana Dengan Penjelasan. Jakarta: Aksara Baru.

-------. (1997). Tentang Delik

Penyertaan, Pekanbaru: UIR Press.

Sambulele Susanty, A. (2013).

Tanggung Jawab Pelaku Penyertaan Dalam Tindak Pidana (Pasal 55 dan 56 KUHP). Jurnal Lex Crimen, Vol. II/No. 7,, pp. 89.

Shidarta. (2006). Karakteristik Penalaran Hukum Dalam Konteks 
Keindonesiaan. Bandung: CV.Utomo. (2013). Hukum Penalaran dan Penalaran Hukum Buku 1 Akar Filosofis. Yogyakarta: Genta Publishing.

. (2010). Peragaan Pola Penalaran Hukum Dalam Kajian Putusan Kasus Tanah Adat. Jurnal Yudisial, Vol-III/No03. pp. 208.

(2013). Konsep 'malum in se' dan 'malum prohibitum' Dalam Filosofi Pemberantasan Korupsi. Jurnal Masalah-Masalah Hukum, Jilid 42 No.1, pp. 89.

Shidarta, Bernard. A. (2000). Refleksi Tentang Struktur Ilmu Hukum Sebuah Penelitian Tentang Fundasi Kefilsafatan dan Sifat Keilmuan Ilmu Hukum Sebagai Landasan Pengembangan Ilmu Hukum Nasional Indonesia. Bandung: Mandar Maju.

Fitriasih, Surastini. (2006). Penerapan Ajaran Penyertaan dalan Peradilan Pidana Indonesia (Studi Kasus Tindak Pidana Korupsi, Pelatggaran HAM Berat dan Terorisme). Universitas Indonesia.

Utrecht. (1965). Hukum Pidana 11. Bandung: Penerbitan Universitas. 